\title{
PENGARUH KUALITAS PELAYANAN, SANKSI PAJAK, KESADARAN WAJIB PAJAK TERHADAP KEPATUHAN WAJIB PAJAK DALAM MEMBAYAR PAJAK BUMI DAN BANGUNAN KECAMATAN TANJUNGKERTA KABUPATEN SUBANG
}

\author{
Oleh: \\ Fanji Farman \\ Universitas Sebelas April, Sumedang \\ email: fanjifarman2501@gmail.com
}

\begin{abstract}
ABSTRAK
Penelitian ini bertujuan untuk mengetahui Pengaruh Kualitas Pelayanan, Sanksi Pajak, dan Kesadaran Wajib Pajak berpengaruh terhadap Kepatuhan Wajib Pajak dalam membayar Pajak Bumi dan Bangunan pada Kecamatan Tanjungkerta Kabupaten Sumedang. Metode yang digunakan dalam penelitian ini adalah metode penelitian kuantitatif dengan pendekatan survey. Teknik pengambilan data diperoleh dari hasil kuesioner dan penelitian kepustakaan. Sampel dalam penelitian ini adalah sebagian wajib pajak PBB pada Kecamatan Tanjungkerta yaitu berjumlah 100 responden. Teknik pengambilan sampel dengan teknik Simple Random Sampling. Teknik analisis data yang digunakan adalah analisis regresi linear berganda dan analisis koefisien determinasi. Berdasarkan hasil penelitian dapat disimpulkan bahwa diperoleh korelasi yang kuat yaitu dengan niali koefisien korelasi ganda 0,716. Kualitas pelayanan, sanksi pajak, kesadaran wajib pajak mempengaruhi kepatuhan wajib pajak sebesar 51,3\% dan sisanya 48,7\% dipengaruhi faktor lain yang tidak termasuk dalam variabel yang diteliti dalam penelitian ini. Dapat dibuktikan hasil analisis berganda yaitu $Y=0,195+0,277 X_{1}+0,340 X_{2}$

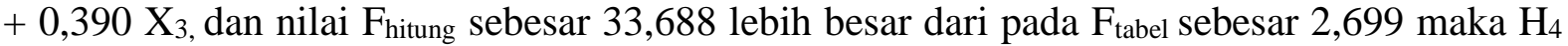
diterima $\mathrm{H}_{0}$ ditolak dan juga jika dilihat dari nilai signifikansi sebesar 0,000 lebih kecil dari 0,05. Hal ini menunjukkan bahwa "Terdapat Pengaruh Positif Signifikan Antara Kualitias Pelayanan, Sanksi Pajak, Kesadaran Wajib Pajak Terhadap Kepatuhan Wajib Pajak”.
\end{abstract}

Kata Kunci: Kualitas Pelayanan, Sanksi Pajak, Kesadaran Wajib Pajak, Pajak Bumi dan Bangunan

\section{ABSTRACT}

This study aims to determine the effect of Service Quality, Tax Sanctions, and Taxpayer Awareness affecting Taxpayer Compliance in paying Land and Building Tax in Tanjungkerta District, Sumedang Regency. The method used in this research is a quantitative research method with a survey approach. The data collection technique was obtained from the results of questionnaires and library research. The sample in this study were some of the PBB taxpayers in the Tanjungkerta District, amounting to 100 respondents. The sampling technique was simple random sampling technique. The data analysis technique used is multiple linear regression analysis and analysis of the coefficient of determination. Based on the research results, it can be concluded that a strong correlation is obtained, namely the multiple correlation coefficient value of 0.716. Service quality, tax sanctions, taxpayer awareness affect taxpayer compliance by $51.3 \%$ and the remaining $48.7 \%$ is influenced by other factors that are not included in the variables examined in this study. It can be proven that the results of multiple 
analysis are $Y=0.195+0.277 X 1+0.340 X 2+0.390 X 3$, and the Fcount value of 33.688 is greater than Ftable of 2.699, then $\mathrm{H} 4$ is accepted $\mathrm{HO}$ is rejected and also if seen from the significance value of 0.000 is smaller than 0, 05. This shows that "There is a Significant Positive Effect Between Service Quality, Tax Sanctions, Taxpayer Awareness of Taxpayer Compliance".

Keywords: Service Quality, Tax Sanctions, Taxpayer Awareness, Taxpayer Compliance, Land and Building Tax

\section{PENDAHULUAN}

\section{Latar Belakang}

Sumber pendapatan Negara dapat berasal dari penghasilan perusahaanperusahaan Negara, dari barang-barang yang dimiliki oleh pemerintah atau barangbarang yang dikuasai oleh pemerintah, serta penerimaan dari berbagai macam pajak. Sebagai salah satu penerimaan bagi negara, pajak sangat diandalkan untuk pembiayaan pembangunan dan pengeluaran Negara. Pajak dapat didefinisikan sebagai iuran rakyat kepada kas Negara berdasarkan Undang-Undang tanpa mendapatkan balas jasa langsung dan digunakan untuk membiayai pengeluaran pemerintah dalam rangka meningkatkan kesejahteraan umum (www.pajak.go.id). Dari definisi tersebut tergambar bahwa salah satu fungsi pajak, ialah sebagai sumber penerimaan Negara (fungsi budgeter).

Salah satu jenis pajak pusat yang wewenangnya akan dilimpahkan kepada daerah yaitu Pajak Bumi dan Bangunan. Dengan diberlakukannya Undang-Undang No. 28 Tahun 2009 tentang Pajak Daerah dan Retribusi Daerah, PBB sektor perdesaan dan perkotaan dialihkan menjadi pajak daerah. Dengan adanya kebijakan tersebut, maka penerimaan jenis pajak ini akan diperhitungkan sebagai pendapatan asli daerah (PAD) yang akan menambah sumber pendapatan asli daerah dan dapat meningkatkan kemampuan daerah dalam membiayai kebutuhan daerahnya sendiri.

Upaya untuk mengoptimalkan penerimaan Pajak Bumi dan Bangunan yaitu dengan meningkatkan kepatuhan wajib pajak. Kepatuhan wajib pajak adalah suatu keadaan dimana wajib pajak memenuhi semua kewajiban perpajakan dan melaksanakan hak perpajakannya. Pada kenyataanya, kepatuhan bukan merupakan tindakan yang mudah untuk direalisasikan oleh setiap wajib pajak. Kendala yang dihadapi pemerintah daerah dalam pelaksanaan pemungutan PBB diantaranya masih kurang kesadaran masyarakat dalam membayar PBB, seperti halnya pada Tabel 1 mengenai data target dan realisasi PBB di Kecamatan Tanjungkerta Kabupaten Sumedang selama tiga tahun terakhir (20182020). 
Tabel 1. Target dan Realisasi PBB Kecamatan Tanjungkerta Kabupaten Sumedang Tahun 2017-2020

\begin{tabular}{cccc}
\hline Tahun & $\begin{array}{c}\text { Realisasi } \\
(\mathbf{R p})\end{array}$ & $\begin{array}{c}\text { Target PBB } \\
(\mathbf{R p})\end{array}$ & Sisa \\
\hline 2018 & 688.858 .100 & 773.146 .934 & 83.753 .946 \\
\hline 2019 & 870.712 .738 & $954,150,112$ & 84.437 .374 \\
\hline 2020 & 813.916 .486 & 1.072 .198 .194 & 259.625 .134 \\
\hline
\end{tabular}

Sumber: Data PBB Kecamatan Tanjungkerta

Menurut data tabel 1.1 realisasi PBB Kecamatan Tanjungkerta Kabupaten Sumedang mengalami naik turun, pada tahun 2018 belum tercapainya target yang direncanakan sebesar Rp. 688.858.100 dari target yang ditetapkan sebesar 773.146.934. Target dan realisasi Pajak Bumi dan
Bangunan mengalami kenaikan pada tahun 2019 sebesar Rp 870.712.738 dari target Rp 954.150.112, dan pada tahun 2020 mengalami penurunan realisasi yang cukup signifikan realisasi anggaran yang didapat sebesar Rp 813.916.486 dari target yang anggaran sebesar Rp 1.072.198.194.

Tabel 2. Persentase Tingkat Kepatuhan PBB Kecamatan Tanjungkerta

\begin{tabular}{cccc}
\hline Tahun & $\mathbf{2 0 1 8}$ & $\mathbf{2 0 1 9}$ & $\mathbf{2 0 2 0}$ \\
\hline Persentase & $89 \%$ & $91,3 \%$ & $75,8 \%$
\end{tabular}

Sumber: Data PBB Kecamatan Tanjungkerta

Menurut data tabel 2 di atas menunjukkan bahwa pelaksanaan pemenuhan kewajiban perpajakan dalam hal penyampaian Surat Pemberitahuan (SPT) di Kecamatan Tanjungkerta sudah cukup baik tapi belum maksimal. Disebutkan cukup baik karena Tingkat kepatuhan yang ditunjukkan dengan persentase tingkat kepatuhan Wajib Pajak PBB di Kecamatan Tanjungkerta dari tahun 2018 sampai dengan 2020 mengalami naik turun. Pada tahun 2019 persentase tingkat kepatuhan menunjukkan angka 91,3\%, besarnya persentase tersebut naik dari tahun sebelumnya yang tercatat sebesar $89 \%$ naik 2,3\% pada tahun 2018. Selanjutnya pada tahun 2020 persentase kepatuhan menunjukkan angka 75,8\% yang mengalami penurunan cukup signifikan sebesar 15,5\% dari tahun 2019. 
Salah satu upaya dalam peningkatan kepatuhan wajib pajak adalah memberikan pelayanan yang baik kepada wajib pajak. Peningkatan kualitas dan kuantitas pelayanan diharapkan dapat meningkatkan kepuasan kepada wajib pajak sehingga wajib pajak akan meningkatkan kepatuhan dalam melaksanakan kewajibannya dalam membayar PBB. Kualitas pelayanan merupakan tingkat keunggulan untuk memenuhi keinginan pelanggan (wajib pajak). Kualitas pelayanan dapat dinilai berdasarkan persepsi konsumen dengan membandingkan harapan saat menerima layanan, dengan pengalaman sebenarnya atas layanan yang telah diterima.

Sanksi yang dikenakan untuk setiap wajib pajak yang melanggar ketentuan peraturan perundang-undangan perpajakan yaitu sanksi administrasi, sanksi pidana atau keduanya. Sanksi administrasi yang dikenakan pada pelanggar pajak berupa bunga, denda, atau kenaikan. Sanksi administrasi berupa bunga sebesar 2\% perbulan, sanksi administrasi berupa denda sebesar 2\% dari dasar pengenaan pajak dan sanksi administrasi berupa kenaikan sebesar $50 \%$ dari jumlah pajak yang kurang bayar. Untuk sanksi pidana berupa kurungan paling lama enam tahun dan denda paling tinggi dua kali jumlah pajak terutang yang tidak atau kurang dibayar, dan sanksi pidana berupa penjara paling lama enam tahun dan denda paling tinggi empat kali jumlah pajak terutang yang tidak atau kurang dibayar.

Apapun upaya pemerintah dalam meningkatkan kepatuhan wajib pajak dalam membayar pajak tetap tidak akan membuat wajib pajak patuh membayar pajaknya kalau bukan kesadaran wajib pajak itu sendiri dalam membayar PBB. Hal tersebut jelas karena kesadaran merupakan sesuatu yang muncul dari hati nurani seseorang. Kesadaran perpajakan harus menjadi perhatian serius bagi pemerintah. Kesadaran wajib pajak merupakan jantung penggerak dalam meningkatkan kepatuhan wajib pajak. Kesadaran masyarakat dalam membayar pajak sangat dibutuhkan. Hal ini mengindikasikan bahwa kesadaran wajib pajak yang paling berpengaruh terhadap kepatuhan wajib pajak.

Kesadaran masyarakat yang rendah seringkali menjadi salah satu penyebab banyaknya potensi pajak yang tidak dapat terjaring. Masih banyak masyarakat Indonesia yang menganggap bahwa penarikan pajak oleh pemerintah akan membebani masyarakat dan kekhawatiran akan penyalahgunaan uang pajak seringkali menjadi pemikiran masyarakat. Wajib Pajak yang memiliki kesadaran yang rendah akan lebih cenderung untuk tidak melaksanakan kewajiban perpajakannya atau akan melanggar peraturan perpajakan yang berlaku. Oleh karena itu, diperlukan kesadaran yang berasal dari diri Wajib Pajak 
itu sendiri akan arti dan manfaat dari pemungutan pajak tersebut.

\section{Rumusan Masalah}

Berdasarkan latar belakang penelitian diatas, Maka penulis merumuskan permasalahan yang akan dibahas dalam penelitian ini adalah sebagai berikut :

1. Bagaimana pengaruh kualitas pelayanan terhadap kepatuhan wajib pajak dalam membayar Pajak Bumi dan Bangunan pada Kecamatan Tanjungkerta.

2. Bagaimana pengaruh sanksi pajak terhadap kepatuhan wajib pajak dalam membayar Pajak Bumi dan Bangunan pada Kecamatan Tanjungkerta.

3. Bagaimana pengaruh kesadaran wajib pajak terhadap kepatuhan wajib pajak dalam membayar Pajak Bumi dan Bangunan pada Kecamatan Tanjungkerta.

4. Bagaimana pengaruh kualitas pelayanan, sanksi pajak, serta kesadaran wajib pajak terhadap kepatuhan wajib pajak dalam membayar pajak bumi dan bangunan pada Kecamatan Tanjungkerta.

\section{Tujuan Penelitian}

Adapun tujuan dari penelitian ini yang ingin dicapai adalah untuk menganalisis:
1. Untuk mengetahui pengaruh kualitas pelayanan terhadap kepatuhan wajib pajak dalam membayar Pajak Bumi dan Bangunan pada Kecamatan Tanjungkerta.

2. Untuk mengetahui pengaruh sanksi pajak terhadap kepatuhan wajib pajak dalam membayar Pajak Bumi dan Bangunan pada Kecamatan Tanjungkerta.

3. Untuk mengetahui pengaruh kesadaran wajib pajak terhadap kepatuhan wajib pajak dalam membayar Pajak Bumi dan Bangunan pada Kecamatan Tanjungkerta.

4. Untuk mengetahui pengaruh kualitas pelayanan, sanksi pajak, serta kesadaran wajib pajak terhadap kepatuhan wajib pajak dalam membayar Pajak Bumi dan Bangunan pada Kecamatan Tanjungkerta.

\section{Tinjauan Pustaka}

Pajak

Menurut Rochmat Soemitro dan Dewi Kania Sugiharti (2014) menjelaskan bahwa Pajak merupakan iuran rakyat kepada kas Negara berdasarkan undang-undang (yang dapat dipaksakan) dengan tiada mendapat jasa timbul (kontraprestasi) yang langsung dapat ditunjukkan dan digunakan untuk membayar pengeluaran umum. 


\section{Wajib Pajak}

Dalam Undang-Undang Republik Indonesia Nomor 16 tahun 2009 tentaang peraturan keempat atas Undang-Undang Republik Indonesia Nomor 6 tahun 1983 tentang ketentuan umum dan tata cara perpajakan dijelaskan bahwa: "Wajib Pajak adalah orang pribadi atau badan, meliputi pembayaran pajak, pemotong pajak, dan pemungut pajak, yang mempuanyai hak dan kewajiban perpajakan sesuai dengan ketentuan peraturan perundang-undangan perpajakan".

\section{Pajak Bumi dan Bangunan}

Pajak Bumi dan Bangunan menurut UU NO 28 tahun 2009 adalah pajak atas bumi dan/atau bangunan yang dimiliki, dikuasai, dan/atau dimanfatkan oleh orang pribadi atau badan, kecuali kawasan yang digunakan untuk kegiatan usaha perkebunan, perhutanan, dan pertambangan.

\section{Kualitas Pelayanan}

Kotler dan Keller (2016) mendefinisikan pelayanan sebagai berikut: "any act or that one party can offer another that is essensially intangible and does not result in the ownership of anything. It's production may or not to be tied to a physical product." Artinya jasa atau layanan adalah semua tindakan atau kinerja yang dapat ditawarkan satu pihak kepada pihak lain yang pada intinya tidak berwujud dan tidak menghasilkan kepemilikan apapun. Produksinya dapat atau tidak terkait dengan produk fisik. Dan menurut Hardiansyah (2018), mengemukakan bahwa kualitas pelayanan adalah pelayanan yang diberikan kepada konsumen sesuai dengan standar pelayanan yang telah dibakukan dalam memberikan layanan sebagai pembakuan pelayanan yang baik.

\section{Sanksi Pajak}

Pengertian sanksi perpajakan menurut Mardiasmo (2019) menyatakan bahwa : "Sanksi perpajakan merupakan jaminan bahwa ketentuan peraturan perundangundangan perpajakan (norma perpajakan) akan dituruti/ditaati/dipatuhi. Atau dengan kata lain sanksi pajak merupakan alat pencegah (preventif) agar wajib pajak tidak melanggar norma perpajakan".

\section{Kesadaran Wajib Pajak}

Menurut Siti Kurnia Rahayu (2017) Kesadaran wajib pajak merupakan : "Kesadaran wajib pajak merupakan kondisi dimana Wajib Pajak mengerti dan memahami arti, fungsi maupun tujuan pembayaran pajak kepada Negara. Dengan kesadaran wajib pajak yang tinggi akan memberikan pengaruh kepada 
meningkatkan kepatuhan pajak yang lebih baik lagi”.

\section{Kepatuhan Wajib Pajak}

Menurut Siti Kurnia Rahayu (2017), mengatakan bahwa : "Kepatuhan perpajakan merupakan ketaatan wajib pajak dalam melaksanakan ketentuan perpajakan yang berlaku. Wajib pajak yang patuh adalah wajib pajak yang taat memenuhi kewajiban perpajakan sesuai ketentuan Peraturan Perundang-Undangan".

\section{Pendapat Asli Daerah (PAD)}

Berdasarkan Undang-undang No. 33 tahun 2004 pasal 1 ayat 13 Pendapatan Asli Daerah merupakan sebuah hak Pemerintah Daerah yang diakui sebagai penambah nilai kekayaan bersih dalam periode tahun bersangkutan. menurut Abdul Halim (2020) mendefinisikan bahwa : "Pendapatan Asli Daerah adalah penerimaan yang diperoleh daerah dari sumber-sumber dalam wilayahnya sendiri yang dipungut berdasarkan peraturan daerah yang sesuai dengan peraturan perundang-undangan yang berlaku."

\section{METODOLOGI PENELITIAN}

\section{Metode Penelitian yang Digunakan}

Agar penelitian lebih terarah serta sesuai dengan tujuan yang diinginkan, penelitian menggunakan pendekatan kuantitatif untuk mengubah data-data yang diperoleh dari lokasi penelitian yang merupakan data yang berupa angka atau kuantitatif yaitu pencarian data/informasi dari realitas permasalahan yang ada dengan mengacu pada pembuktian konsep/teori yang digunakan. Dalam memperoleh data dan informasi yang diperlukan, penulis melakukan penelitian di Kecamatan Tanjungkerta Kabupaten Sumedang yang bertempat di Sindangtaman Sukamantri, Tanjungkerta, Kabupaten Sumedang, Jawa Barat 45354

\section{Operasionalisasi Variabel Penelitian Varibel Independen}

Variabel independen sering disebut variabel stimulus, predictor, antecedent. Dalam bahasa Indonesia sering disebut sebagai variabel bebas yang mempengaruhi atau yang menjadi sebab perubahannya atau timbulnya variabel dependen/terikat (Sugiyono,2020). Dalam penelitian ini, terdapat tiga variabel independen atau variabel bebas $(\mathrm{X})$ yaitu :

$\mathrm{X}_{1}=$ Kualitas Pelayanan Pajak

$\mathrm{X}_{2}=$ Sanksi Pajak

$\mathrm{X}_{3}=$ Kesadaran Wajib Pajak

\section{Varibel Dependen}

Variabel dependen adalah tipe variabel yang dijelaskan atau dipengaruhi oleh variabel independen. Variabel dependen sering disebut sebagai variabel output, kriteria, konsekuen. Dalam bahasa Indonesia sering disebut sebagai variabel 
terikat. Variabel terikat merupakan variabel yang dipengaruhi atau yang menjadi akibat, karena adanya variabel bebas (Sugiyono,2020). Dalam penelitian ini, variabel dependen atau variabel terikat (Y) yaitu :

$\mathrm{Y}=$ Kepatuhan Wajib Pajak

\section{Teknik Pengumpulan Data Populasi}

Berdasarkan penelitian ini, populasi penelitiannya adalah seluruh Wajib Pajak (SPPT) yang tercatat di wilayah Kecamatan Tanjungkerta Kabupaten Sumedang. Jumlah wajib pajak yang ada di Kecamatan Tanjungkerta Kabupaten Sumedang adalah 31.106 Wajib Pajak.

\section{Sampel}

Pengukuran sampel salah satu langkah untuk menentukan besarnya jumlah sampel yang diambil dalam pelaksanaan penelitian. Sampel harus menggambarkan keadaan populasi yang sebenarnya atau yang mewakili. Adapun cara pengambilan sampel pada penelitian ini dengan menggunakan simple random sampling.

Menurut Sugiyono (2020) "Simple random sampling adalah pengambilan anggota sampel dari populasi dilakukan secara acak tanpa memperhatikan strata yang ada dalam populasi itu".

Berdasarkan penjelasan diatas, maka peneliti akan menggunakan sampel dengan menggunakan rumus Solvin, sampel yang ditentukan oleh penulis dengan presentase kelonggaran ketidaktelitian adalah sebesar $10 \%$

$$
\text { Rumus Solvin }=\frac{N}{1+N e^{2}}
$$

Keterangan:

$\mathrm{n}=$ Jumlah Sampel

$\mathrm{N}=$ Jumlah Populasi

$\mathrm{e}=$ Tingkat Kesalahan dalam Memilih Anggota Sampel yang ditolerir sebesar $10 \%$

\section{Pengujian Data}

\section{Uji Validitas}

Untuk menguji validitas pada tiap-tiap item, yaitu dengan mengkorelasikan skor tiap butir dengan skor total yang merupakan jumlah tiap skor butir. Koefisen kolerasi yang dihasilkan kemudian dibandingkan dengan standar validasi yang berlaku. Menurut Sugiyono (2020) :

a. Jika $\geq 0,30$, maka item instrumen dinyatakan valid

b. Jika $\leq 0,30$, maka item instrumen dinyatakan tidak valid

\section{Uji Reliabilitas Instrumen}

Uji Reliabilitas dilakukan untuk menguji kehandalan/konsistensi instrument. Item-item yang dilibatkan dalam uji reliabilitas adalah seluruh item yang valid atau setelah item yang tidak valid disisihkan. 
Untuk melihat reliabilitas masing-masing instrumen dalam penelitian ini digunakan koefisien Cronbach Alpha ( $\alpha$ ) dengan menggunakan fasilitas SPSS. Pemberian interprestasi terhadap reliabilitas suatu variabel dikatakan reliabel jika nilai Cronbach Alpha $>$ 0,60 atau nilai korelasi hasil perhitungan lebih besar daripada nilai dalam tabel dan dapat digunakan untuk penelitian.

\section{Uji Normalitas}

Penggunaan statistik parametris mensyaratkan bahwa data setiap variabel yang akan dianalisis harus distribusi normal. Oleh karena itu sebelum pengujian hipotesis dilakukan maka terlebih dahulu harus dilakukan normalitas data. Uji normalitas dalam penelitian ini menggunakan metode Kolmogrov Smirnov, menurut Ghozali (2018) jika hasil angka signifikansi (Sig) lebih kecil dari 0,05 maka data tidak terdistribusi normal.

\section{Uji Multikolonieritas}

Bertujuan untuk menguji model regresi ditemukan adanya korelasi antara variabel bebas (independen). Model regresi yang baik seharusnya tidak terjadi korelasi diantara variabel bebas. Jika variabel bebas saling berkorelasi, maka variabel-variabel ini tidak orthogonal. Variabel orthogonal adalah variabel bebas uang nilai korelasi antara sesama variabel bebas sama dengan nol. Langkah menganalisis asumsi

multikolonieritas yaitu:

a. Tidak terjadinya multikolonieritas, jika nilai tolerance lebih besar 0.10 .

b. Terjadi multikolonieritas, jika nilai tolerance lebih kecil atau sama dengan 0.10 .

c. Jika nilai VIF (variance inflation factor) lebih kecil dari angka 10.00 maka tidak terjadi problem multikolonieritas.

d. Jika nilai VIF lebih dari angka 10 maka terjadi problem multikolonieritas.

\section{Uji Heterosdastisitas}

Bertujuan menguji apakah dalam modal regresi terjadi ketidaksamaan variance dari residual satu pengamatan ke pengamatan yang lain. Jika variance dari residual suatu pengamatan ke pengamatan yang tetap, maka disebut Homoskesdastisitas dan jika berbeda disebut heterosdastisitas. Kebanyakan data cross sections mengandung situasi Heterosdastisitas karena data ini menghimpun data yang mewakili berbagai ukuran (kecil, sedang, dan besar). Cara menganalisi asumsi Heterosdastisitas dengan melihat grafit scatter plot dimana:

a. Jika penyebaran data pada scatterplot teratur dan membentuk pola tertentu (naik turun, mengelompok menjadi satu) maka dapat disimpulkan terjadi problem heterosdastisitas.

b. Jika penyebaran data pada scatterplot tidak teratur dan tidak membentuk 
pola tertentu (naik turun, mengelompok menjadi satu) maka dapat disimpulkan tidak terjadi problem heterosdastisitas.

$$
Y=\alpha+\beta_{1} x_{1}+\beta_{2} x_{2}+\beta_{3} x_{3}+e
$$

Keterangan

\section{Rancangan Analisis dan Uji Hipotesis Rancangan Analisis Data}

Analisis data merupakan kegiatan setelah data seluruh responden terkumpul. Kegiatan dalam analisis data adalah mengelompokkan data berdasarkan variabel dan jenis responden, mentabulasi data berdasarkan variabel dari seluruh responden, menyajikan data dari setiap variabel yang diteliti, melakukan perhitungan untuk menjawab rumusan masalah dan melakukan perhitungan untuk menguji hipotesis yang diajukan (Sugiyono 2019 : 147).

\section{a. Analisis Regeresi Linear Berganda}

Regresi linear berganda adalah analisis regresi yang menjelaskan hubungan antara perubahan respon (variabel dependen) dengan faktor-faktor yang mempengaruhi lebih dari satu prediktor (variabel independen). Analisis regresi digunakan untuk menguji hipotesis tentang pengaruh secara persial variabel bebas terhadap variabel terikat. Persamaan umum regresi linear berganda adalah :

\section{b. Analisis Koefisien Determinasi}

Untuk mengetahui besarnya pengaruh Kualitas Pelayanan, Sanksi Pajak dan Kesadaran Wajib Pajak terhadap Kepatuhan Wajib Pajak, dilakukan analisis menggunakan koefisien determinasi. Koefisien determinasi dihitung dengan rumus :

$$
\mathrm{KD}=\mathrm{rs}^{2} \times 100 \%
$$

$\mathrm{KD}=$ Koefisien Determinasi

rs $\quad=$ Koefisien Korelasi

Metode untuk mencari koefisien determinasi dilakukan dengan menggunakan bantuan software statistical for social science (SPSS) versi 25. 
Pelayanan, Sanksi Pajak, dan Kesadaran Wajib Pajak terhadap

\section{Uji Hipotesis}

Hipotesis merupakan jawaban sementara yang akan diuji dan dibuktikan kebenarannya. Uji signifikasi pengaruh variabel independen terhadap variabel dependen secara persial menggunakan uji $t$ dan secara simultan menggunakan uji F.

\section{a. Pengujian Hipotesis secara Parsial (Uji $t)$}

Menggunakan rumus uji signifikansi koefisien (uji $\mathrm{t}$ student) dengan cara membandingkan $t_{\text {hitung }}$ dan $t_{\text {tabel }}$ dengan rumus :

$$
t=\frac{r \sqrt{n-2}}{\sqrt{1-r^{2}}}
$$

Sumber: Sugiyono (2019:184)

Keterangan:

$\mathrm{t}=$ Nilai $\mathrm{t}$ hitung

$\mathrm{n}=$ Jumlah sampel

$\mathrm{r}=$ Koefisien korelasi hasil hitung

Dimana hipotesis yang diajukan

adalah sebagai berikut

$\mathrm{H}_{0}: \rho=0:$ Tidak terdapat pengaruh positif yang signifikan antara Kualitas Pelayanan, Sanksi Pajak, dan Kesadaran Wajib Pajak terhadap Kepatuhan Wajib Pajak.

Ha $: \rho \neq 0:$ Terdapat pengaruh positif yang signifikan antara Kualitas
Kepatuhan Wajib Pajak.

Dengan tingkat sifnifikan $\alpha=5 \%$ $(0,05)$ dan derajat kebebasan $(\mathrm{dk})=\mathrm{n}-3$

Dari hasil perhitungan uji t tersebut kemudian hasil $\mathrm{t}$ hitung dibandingkan dengan $\mathrm{t}$ tabel dengan kriteria :

1. $t_{\text {hitung }}>\mathrm{t}_{\text {tabel}}$, maka $\mathrm{H}_{\mathrm{a}}$ diterima dan $\mathrm{H}_{0}$ ditolak berarti terdapat pengaruh yang signifikan antara Kualitas Pelayanan, Sanksi Pajak Dan Kesadaran Wajib Pajak terhadap Kepatuhan Wajib Pajak.

2. $t_{\text {hitung }}<t_{\text {tabel }}$, maka $\mathrm{H}_{\mathrm{a}}$ ditolak dan $\mathrm{H}_{0}$ diterima berarti tidak terdapat pengaruh yang signifikan antara Kualitas Pelayanan, Sanksi Pajak Dan Kesadaran Wajib Pajak terhadap Kepatuhan Wajib Pajak.

\section{b. Pengujian hipotesis secara simultan (Uji F) \\ Uji F (uji simultan) adalah untuk} melihat apakah variabel independen secara bersama-sama (serentak) mempunyai pengaruh yang signifikan terhadap variabel dependen. Pada pengujian secara srimultan akan diuji pengaruh ke dua variabel independen terhadap variabel dependen. Statistik uji yang digunakan pada pengujian simultan adalah uji $\mathrm{F}$ dengan rumus sebagai berikut : 


$$
F h=\frac{R^{2} / k}{1-R^{2}(n-k-1)}
$$

Sumber: Sugiyono (2019)

Dimana :

$\mathrm{R}=$ Koefisien korelasi ganda

$\mathrm{K}=$ Jumlah variabel independen

$\mathrm{n}=$ Jumlah anggota sampel

Untuk pengujian pengaruh simultan digunakan rumus hipotesis sebagai berikut : $H_{o}: \beta_{1}=0$ : Kualitas Pelayanan, Sanksi Pajak, dan Kesadaran Wajib Pajak secara simultan tidak berpengaruh positif terhadap Kepatuhan Wajib Pajak.

$\mathrm{H}_{\mathrm{o}}: \beta_{1} \neq 0$ : Kualitas Pelayanan, Sanksi Pajak, dan Kesadaran Wajib Pajak secara simultan berpengaruh positif terhadap Kepatuhan Wajib Pajak.

Kriteria pengujian $\mathrm{f}$ membandingkan nilai $f_{\text {hitung }}$ dengan $f_{\text {tabel }}$ menggunakan tabel harga kritis ftabel dan tingkat signifikansi yang telah ditentukan 0,01 dan $0,05(\alpha=$ $0,01$ dan $\alpha=0,05)$.

1. $t_{\text {hitung }}>t_{\text {tabel}}$, maka $\mathrm{H}_{\mathrm{a}}$ diterima dan $\mathrm{H}_{0}$ ditolak berarti terdapat pengaruh yang signifikan antara Kualitas Pelayanan, Sanksi Pajak Dan Kesadaran Wajib Pajak terhadap Kepatuhan Wajib Pajak.
2. $t_{\text {hitung }}<t_{\text {tabel }}$, maka $\mathrm{H}_{\mathrm{a}}$ ditolak dan $\mathrm{H}_{0}$ diterima berarti tidak terdapat pengaruh yang signifikan antara Kualitas Pelayanan, Sanksi Pajak Dan Kesadaran Wajib Pajak terhadap Kepatuhan Wajib Pajak.

\section{HASIL PENELITIAN DAN PEMBAHASAN}

\section{Analisis Data}

\section{Uji Validitas}

Variabel Kualitas Pelayanan (X1) diukur dengan 21 item pernyataan. Berikut adalah hasil uji validitas untuk Variabel Kualitas Pelayanan (X1). Hasil perhitungan nilai korelasi di atas menunjukkan bahwa butir-butir kuesioner Kualitas Pelayanan (X1) dalam penelitian ini adalah valid. Hal ini ditunjukkan dengan nilai $r_{\text {hitung }}$ untuk masing masing item lebih besar dari $r_{\text {tabel }}$ (0.3). Artinya duapuluh satu butir pernyataan variabel Kualitas Pelayanan (X1) memiliki tingkat validitas yang baik dan dapat mengukur variabel Kualitas Pelayanan (X1) yang diteliti.

Variabel Sanksi pajak (X2) diukur dengan 5 item pernyataan. Berikut adalah hasil uji validitas untuk Variabel Sanksi Pajak (X2). Hasil perhitungan nilai korelasi menunjukkan bahwa butir-butir kuesioner Sanksi Pajak (X2) dalam penelitian ini adalah valid. Hal ini ditunjukkan dengan nilai $r_{\text {hitung }}$ untuk masing masing item lebih besar dari $r_{\text {tabel }}(0.3)$. Artinya lima butir 
pernyataan variabel Sanksi Pajak (X2) memiliki tingkat validitas yang baik dan dapat mengukur variabel Sanksi Pajak (X2) yang diteliti.

Variabel Kesadaran Wajib Pajak (X3) diukur dengan 6 item pernyataan. Berikut adalah hasil uji validitas untuk Variabel Kesadaran Wajib Pajak (X3). Hasil perhitungan nilai korelasi menunjukkan bahwa butir-butir kuesioner Kesadaran Wajib Pajak (X3) dalam penelitian ini adalah valid. Hal ini ditunjukkan dengan nilai $\mathrm{r}_{\text {hitung }}$ untuk masing masing item lebih besar dari $r_{\text {tabel }}(0.3)$. Artinya enam butir pernyataan variabel Kesadaran Wajib Pajak (X3) memiliki tingkat validitas yang baik dan dapat mengukur variabel Kesadaran Wajib Pajak (X3) yang diteliti.

Variabel Kepatuhan wajib pajak (Y) diukur dengan 4 item pernyataan. Berikut adalah hasil uji validitas untuk Variabel Kepatuhan Wajib Pajak (Y). Hasil perhitungan nilai korelasi menunjukkan bahwa butir-butir kuesioner Kepatuhan Wajib Pajak (Y) dalam penelitian ini adalah valid. Hal ini ditunjukkan dengan nilai $\mathrm{r}_{\text {hitung }}$ untuk masing masing item lebih besar dari $\mathrm{r}_{\text {tabel }}$ (0.3). Artinya empat butir pernyataan variabel Kepatuhan Wajib Pajak (Y) memiliki tingkat validitas yang baik dan dapat mengukur variabel Kepatuhan Wajib Pajak (Y) yang diteliti.

\section{Uji Reliabilitas}

Nilai reliabilitas yang diperoleh untuk variabel Kualitas Pelayanan sebesar 0,929 lebih besar dari nilai kritis 0,6. Hasil pengujian ini menunjukkan bahwa alat ukur yang digunakan reliabel sehingga dapat disimpulkan bahwa alat ukur yang digunakan untuk mengukur variabel Kualitas Pelayanan sudah memberikan hasil yang konsisten.

Nilai reliabilitas yang diperoleh untuk variabel Sanksi pajak sebesar 0,809 lebih besar dari nilai kritis 0,6. Hasil pengujian ini menunjukkan bahwa alat ukur yang digunakan reliabel sehingga dapat disimpulkan bahwa alat ukur yang digunakan untuk mengukur variabel Sanksi Pajak sudah memberikan hasil yang konsisten.

Nilai reliabilitas yang diperoleh untuk variabel Kesadaran wajib pajak sebesar 0,864 lebih besar dari nilai kritis 0,6. Hasil pengujian ini menunjukkan bahwa alat ukur yang digunakan reliabel sehingga dapat disimpulkan bahwa alat ukur yang digunakan untuk mengukur variabel Kesadaran Wajib Pajak sudah memberikan hasil yang konsisten.

Nilai reliabilitas yang diperoleh untuk variabel Kepatuhan wajib pajak sebesar 0,794 lebih besar dari nilai kritis 0,6. Hasil pengujian ini menunjukkan bahwa alat ukur 
yang digunakan reliabel sehingga dapat disimpulkan bahwa alat ukur yang digunakan untuk mengukur variabel Kepatuhan Wajib Pajak sudah memberikan hasil yang konsisten.

\section{Uji Normalitas}

Hasil perhitungan uji normalitas menggunakan uji Kolmogorov-smirnov yang diperoleh melalui perhitungan SPSS adalah sebagai berikut nilai $\mathrm{t}_{\text {hitung }}$ (Test Statistic) $=0,086$ dengan $\mathrm{p}$-value (nilai sig) sebesar 0,068. Nilai signifikansi uji berada diatas nilai signifikansi sebesar 0,05 , ini berarti bahwa data nilai residual model regresi yang digunakan didalam penelitian ini terdistribusi normal. Hasil pengujian normalitas model regresi menunjukkan bahwa nilai residual dari model berdistribusi normal.

\section{Uji Multikolonieritas}

Dapat diketahui bahwa nilai Variance Inflation Factor (VIF) ketiga variabel $(1,693 ; 1,807 ; 1,365)$ lebih kecil dari 10, maka bisa disimpulkan bahwa antar variabel tidak terjadi masalah multikolinearitas dan layak digunakan.

\section{Uji Heterosdastisitas}

Menunjukkan pola atau bentuk tertentu, tampak titik menyebar secara acak serta data menyebar secara merata di atas sumbu X maupun di atas sumbu Y, maka dapat disimpulkan bahwa tidak terjadi heteroskedastisitas pada model regresi linier.

\section{Analisis Korelasi}

Tabel 3. Hasil Koefisien Korelasi Antar Variabel

\begin{tabular}{|c|c|c|c|c|c|}
\hline \multicolumn{6}{|c|}{ Correlations $^{\mathrm{b}}$} \\
\hline & & $\begin{array}{c}\text { X1 } \\
\text { (Kualitas } \\
\text { Pelayanan) }\end{array}$ & $\begin{array}{c}\text { X2 } \\
\text { (Sanksi } \\
\text { Pajak) }\end{array}$ & $\begin{array}{c}\text { X3 } \\
\text { (Kesadaran } \\
\text { WP) }\end{array}$ & $\begin{array}{l}\text { Y (Kepatuhan } \\
\text { Wajib Pajak) }\end{array}$ \\
\hline \multirow{2}{*}{$\begin{array}{l}\text { X1 (Kualitas } \\
\text { Pelayanan) }\end{array}$} & Pearson Correlation & 1 & $.622^{* * *}$ & $.434^{* * *}$ & $.547^{* *}$ \\
\hline & Sig. (2-tailed) & & .000 & .000 & .000 \\
\hline \multirow{2}{*}{ X2 (Sanksi Pajak) } & Pearson Correlation & $.622^{* * *}$ & 1 & $.490^{* * *}$ & $.606^{* *}$ \\
\hline & Sig. (2-tailed) & .000 & & .000 & .000 \\
\hline \multirow{2}{*}{$\begin{array}{l}\text { X3 (Kesadaran } \\
\text { Wajib Pajak) }\end{array}$} & Pearson Correlation & $.434^{* *}$ & $.490^{* *}$ & 1 & $.601^{* * *}$ \\
\hline & Sig. (2-tailed) & .000 & .000 & & .000 \\
\hline \multirow{2}{*}{$\begin{array}{l}\text { Y (Kepatuhan Wajib } \\
\text { Pajak) }\end{array}$} & Pearson Correlation & $.547^{* * *}$ & $.606^{* *}$ & $.601^{* *}$ & 1 \\
\hline & Sig. (2-tailed) & .000 & .000 & .000 & \\
\hline $\begin{array}{l}* * \text {. Correlation is sign } \\
\text { b. Listwise } \mathrm{N}=100\end{array}$ & ant at the 0.01 level & & & & \\
\hline
\end{tabular}

Sumber : output SPSS25 
korelasi antara Kesadaran wajib pajak

Dari hasil perhitungan yang dapat dilihat pada tabel 3 diperoleh korelasi antara Kualitas pelayanan dengan Kepatuhan wajib pajak sebesar 0,547. Jadi dapat dikatakan ada kaitan yang cukup kuat antara Kualitas pelayanan dengan Kepatuhan wajib pajak. Dari hasil perhitungan diperoleh korelasi antara Sanksi pajak, dengan Kepatuhan wajib pajak sebesar 0,606. Jadi dapat dikatakan ada kaitan yang kuat antara Sanksi pajak dengan Kepatuhan wajib pajak. Dari hasil perhitungan diperoleh dengan Kepatuhan Wajib Pajak sebesar 0,601. Jadi dapat dikatakan ada kaitan yang kuat antara Kesadaran wajib pajak dengan Kepatuhan wajib pajak.

Untuk mengetahui besarnya hubungan secara bersama-sama Kualitas pelayanan, Sanksi pajak, dan Kesadaran wajib pajak terhadap Kepatuhan wajib pajak dapat dilihat nilai korelasi (R). Hasil perhitungan koefisien korelasi ganda untuk persamaan regresi yang diperoleh dapat dilihat pada tabel 4.

Tabel 4. Hasil Koefisien Korelasi Ganda

\begin{tabular}{|c|c|c|c|c|}
\hline \multicolumn{5}{|c|}{ Model Summary } \\
\hline Model & $\mathrm{R}$ & R Square & Adjusted R Square & Std. Error of the Estimate \\
\hline 1 & $.716^{\mathrm{a}}$ & .513 & .498 & .41572 \\
\hline
\end{tabular}

Sumber : Hasil Pengolahan SPSS 25

Dari hasil perhitungan yang dapat dilihat pada tabel 4 diperoleh korelasi antara Kualitas pelayanan, Sanksi pajak, dan Kesadaran wajib pajak secara bersama sama dengan Kepatuhan wajib pajak sebesar 0,716. Jadi dapat dikatakan ada kaitan yang kuat antara Kualitas pelayanan, Sanksi pajak, dan Kesadaran wajib pajak dengan Kepatuhan wajib pajak.

\section{Uji Hipotesis}

\section{a. Pengujian Hipotesis Secara Simultan}

Untuk menguji pengaruh variabel bebas (Kualitas Pelayanan, Sanksi Pajak, dan Kesadaran Wajib Pajak) secara bersama-sama terhadap variabel terikat (Kepatuhan Wajib Pajak) digunakan Uji F. Hipotesis yang diuji adalah sebagai berikut : 
$\mathrm{Ho}_{1}: \beta_{1}=\beta_{2}=\beta_{3}=0$

Tidak terdapat pengaruh signifikan antara variabel Kualitas Pelayanan $\left(\mathrm{X}_{1}\right)$, Sanksi Pajak $\left(\mathrm{X}_{2}\right)$ dan Kesadaran Wajib Pajak $\left(\mathrm{X}_{3}\right)$ terhadap Kepatuhan Wajib Pajak (Y)
$\mathrm{Ha}_{1}$ : Ada $\beta_{i} \neq 0$

Tidak terdapat pengaruh signifikan antara variabel Kualitas Pelayanan $\left(\mathrm{X}_{1}\right)$, Sanksi Pajak $\left(\mathrm{X}_{2}\right)$ dan Kesadaran Wajib Pajak $\left(\mathrm{X}_{3}\right)$ terhadap Kepatuhan Wajib Pajak (Y)

Nilai statistik uji $\mathrm{F}$ diperoleh dalam tabel Anova hasil SPSS. Hasil penghitungan uji Fdapat dilihat pada tabel dibawah ini :

Tabel 5. ANOVA Untuk Uji Signifikansi

\begin{tabular}{|c|c|c|c|c|c|c|}
\hline \multicolumn{7}{|c|}{ ANOVA $^{a}$} \\
\hline Model & & Sum of Squares & $\mathrm{df}$ & Mean Square & $\mathrm{F}$ & Sig. \\
\hline \multirow{3}{*}{1} & Regression & 17.466 & 3 & 5.822 & 33.688 & $.000^{\mathrm{b}}$ \\
\hline & Residual & 16.591 & 96 & .173 & & \\
\hline & Total & 34.057 & 99 & & & \\
\hline
\end{tabular}

a. Dependent Variable: Y (Kepatuhan Wajib Pajak)

b. Predictors: (Constant), X3 (Kesadaran Wajib Pajak), X1 (Kualitas Pelayanan), X2 (Sanksi Pajak)

Sumber : Hasil Pengolahan SPSS 25

Diperoleh nilai $F_{\text {hitung }}$ sebesar 33,688 dengan signifikansi 0,000 . Untuk menguji hipotesis dilakukan dengan membandingkan antara $F_{\text {hitung }}$ dengan nilai $F_{\text {tabel. }}$. Dari tabel $F$ diperoleh nilai $\mathrm{F}_{\text {tabel }}$ dengan $\mathrm{db}_{1}=3$ dan $\mathrm{db}_{2}$ $=100-3-1=96$ sebesar 2,699.

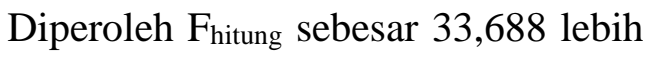
besar dari pada $\mathrm{F}_{\text {tabel }}$ sebesar 2,699 dan juga jika dilihat dari nilai signifikansi sebesar 0,000 lebih kecil dari 0,05. Sehingga dapat disimpulkan secara bersama-sama Kualitas Pelayanan, Sanksi Pajak, dan Kesadaran Wajib Pajak berpengaruh nyata terhadap Kepatuhan Wajib Pajak.

\section{b. Pengujian Hipotesis Secara Parsial}

Untuk keperluan mengetahui variabel yang berpengaruh secara signifikan dilakukan pengujian koefisien regresi secara parsial dengan menggunakan statistik uji t. Penentuan hasil pengujian (penerimaan/ penolakan $\mathrm{H}_{0}$ ) dapat dilakukan dengan membandingkan $t_{\text {hitung }}$ dengan $t_{\text {tabel }}$ atau juga dapat dilihat dari nilai signifikansinya. Nilai $\mathrm{t}_{\text {tabel }}$ dengan taraf kesalahan $5 \%$ dan $\mathrm{db}=\mathrm{n}-$ $\mathrm{k}-1=100-3-1=96$ adalah 1,985 .

Nilai statsitik uji t yang digunakan pada pengujian secara parsial dapat dilihat pada tabel berikut: 
Tabel 6. Hasil Uji Parsial (Uji t)

\begin{tabular}{|c|c|c|c|c|c|}
\hline \multicolumn{6}{|c|}{ Coefficients $^{\mathrm{a}}$} \\
\hline & & \multicolumn{2}{|c|}{ Unstandardized Coefficients } & \multirow[b]{2}{*}{$\mathrm{T}$} & \multirow[b]{2}{*}{ Sig. } \\
\hline \multicolumn{2}{|c|}{ Model } & B & Std. Error & & \\
\hline \multirow{4}{*}{1} & (Constant) & .195 & .255 & .765 & .446 \\
\hline & X1 (Kualitas Pelayanan) & .277 & .128 & 2.158 & .033 \\
\hline & X2 (Sanksi Pajak) & .340 & .108 & 3.155 & .002 \\
\hline & X3 (Kesadaran Wajib Pajak) & .390 & .088 & 4.402 & .000 \\
\hline
\end{tabular}

1. Pengaruh Kualitas Pelayanan Terhadap Kepatuhan Wajib Pajak

Untuk melihat pengaruh Kualitas Pelayanan terhadap Kepatuhan Wajib Pajak, hipotesis statistik yang digunakan adalah sebagai berikut:

$\begin{aligned} \mathrm{H}_{01}: \beta_{1}=0 & \text { Tidak terdapat pengaruh } \\ & \text { signifikan antara variabel } \\ & \text { Kualitas Pelayanan }\left(\mathrm{X}_{1}\right)\end{aligned}$

terhadap Kepatuhan Pajak (Y)

$\mathrm{Ha}_{1}: \beta_{1} \neq 0 \quad$ Terdapat pengaruh signifikan antara variabel Kualitas Pelayanan $\left(\mathrm{X}_{1}\right)$ terhadap Kepatuhan Wajib Pajak (Y)

Diperoleh nilai thitung untuk $\mathrm{X}_{1}$ sebesar 2,158 dengan signifikansi 0,033. Hasil perhitungan statistik uji pada pengujian hipotesis dirangkum pada tabel 7

Tabel 7. Hasil Uji t untuk Variabel $\mathrm{X}_{1}$

\begin{tabular}{ccccccc}
\hline Hipotesis & $\mathbf{t}_{\text {hitung }}$ & Sig $(\mathbf{p})$ & $\mathbf{t}_{\text {tabel }}$ & $\boldsymbol{\alpha}$ & Keputusan & Keterangan \\
\hline $\mathrm{H} 0: \beta_{1}=0$ & 2,158 & 0,033 & 1,985 & $5 \%$ & $\mathrm{H}_{0}$ ditolak & Signifikan \\
\hline
\end{tabular}

Sumber : Hasil Pengolahan SPSS25

Hasil penghitungan nilai statistik uji $\mathrm{t}$ yang diperoleh menunjukkan t-hitung untuk variabel independen Kualitas Pelayanan $\left(\mathrm{X}_{1}\right)$ lebih besar dari nilai $\mathrm{t}_{\text {tabel }}(\mathrm{t}=2,158>$ 1,985), maka diperoleh hasil pengujian $\mathrm{H}_{1}$ diterima Ho ditolak. Hasil ini juga ditunjukkan oleh nilai signifikansi uji statistik (p-value) $(0,033)$ lebih kecil dari tingkat kesalahan yang dapat diterima sebesar 5\%. Jadi dapat disimpulkan terdapat pengaruh yang signifikan (yang bermakna) 
dari Kualitas pelayanan terhadap Kepatuhan Wajib Pajak.

\section{Pengaruh Sanksi Pajak terhadap Kepatuhan Wajib Pajak}

Untuk melihat pengaruh Sanksi pajak terhadap Kepatuhan Wajib Pajak, hipotesis statistik yang digunakan adalah sebagai berikut:

$\mathrm{H}_{02}: \beta_{2}=0$ Tidak terdapat pengaruh signifikan antara variabel
Sanksi Pajak $\left(\mathrm{X}_{2}\right)$ terhadap Kepatuhan Wajib Pajak (Y)

$\mathrm{Ha}_{2}: \beta_{2} \neq 0 \quad$ Terdapat pengaruh signifikan antara variabel Sanksi Pajak $\left(\mathrm{X}_{2}\right)$ terhadap Kepatuhan Wajib Pajak (Y)

Diperoleh nilai thitung untuk $\mathrm{X}_{2}$ sebesar 3,155 dengan signifikansi 0,002. Hasil perhitungan statistik uji pada pengujian hipotesis dirangkum pada tabel 8

Tabel 8. Hasil Uji t untuk Variabel $\mathrm{X}_{2}$

\begin{tabular}{ccccccc}
\hline Hipotesis & $\mathbf{t}_{\text {hitung }}$ & Sig $(\mathbf{p})$ & $\mathbf{t}_{\text {tabel }}$ & $\boldsymbol{\alpha}$ & Keputusan & Keterangan \\
\hline $\mathrm{H} 0: \beta_{2}=0$ & 3,155 & 0,002 & 1,985 & $5 \%$ & $\mathrm{H}_{0}$ ditolak & Signifikan \\
\hline
\end{tabular}

Sumber : Hasil Pengolahan SPSS25

Hasil penghitungan nilai statistik uji t yang diperoleh menunjukkan t-hitung untuk variabel independen Sanksi pajak $\left(\mathrm{X}_{2}\right)$ lebih besar dari nilai $t_{\text {tabel }}(\mathrm{t}=3,155>1,985)$, maka diperoleh hasil pengujian $\mathrm{H}_{2}$ diterima $\mathrm{Ho}$ ditolak. Hasil ini juga ditunjukkan oleh nilai signifikansi uji statistik (p-value) $(0,002)$ lebih kecil dari tingkat kesalahan yang dapat diterima sebesar 5\%. Jadi dapat disimpulkan terdapat pengaruh yang signifikan (yang bermakna) dari Sanksi Pajak terhadap Kepatuhan Wajib Pajak.

\section{Pengaruh Kesadaran Wajib Pajak terhadap Kepatuhan Wajib Pajak}

Untuk melihat pengaruh Kesadaran wajib pajak terhadap Kepatuhan wajib pajak, hipotesis statistik yang digunakan adalah sebagai berikut:

$\mathrm{H}_{03}: \beta_{3}=0$ Tidak terdapat pengaruh signifikan antara variabel Kesadaran Wajib Pajak $\left(\mathrm{X}_{3}\right)$ terhadap Kepatuhan Wajib Pajak (Y)

$\mathrm{Ha}_{3}: \beta_{3} \neq 0 \quad$ Terdapat pengaruh signifikan antara variabel Kesadaran Wajib Pajak $\left(\mathrm{X}_{3}\right)$ terhadap Kepatuhan Wajib Pajak (Y) Diperoleh nilai thitung untuk $\mathrm{X}_{3}$ sebesar 4,402 dengan signifikansi 0,000. Hasil 
perhitungan statistik uji pada pengujian

hipotesis dirangkum pada tabel 9

Tabel 9. Hasil Uji t untuk Variabel $X_{3}$

\begin{tabular}{ccccccc}
\hline Hipotesis & $\mathbf{t}_{\text {hitung }}$ & Sig $(\mathbf{p})$ & $\mathbf{t}_{\text {tabel }}$ & $\boldsymbol{\alpha}$ & Keputusan & Keterangan \\
\hline $\mathrm{H} 0: \beta_{3}=0$ & 4,402 & 0,000 & 1,985 & $5 \%$ & $\mathrm{H}_{0}$ ditolak & Signifikan
\end{tabular}

Sumber : Hasil Pengolahan SPSS

Hasil penghitungan nilai statistik uji $\mathrm{t}$ yang diperoleh menunjukkan t-hitung untuk variabel independen Kesadaran Wajib Pajak $\left(\mathrm{X}_{3}\right)$ lebih besar dari nilai $\mathrm{t}_{\text {tabel }}(\mathrm{t}=4,402>$ 1,985), maka diperoleh hasil pengujian $\mathrm{H}_{3}$ diterima Ho ditolak. Hasil ini juga ditunjukkan oleh nilai signifikansi uji statistik (p-value) $(0,000)$ lebih kecil dari tingkat kesalahan yang dapat diterima sebesar 5\%. Jadi dapat disimpulkan terdapat pengaruh yang signifikan (yang bermakna) dari Kesadaran Wajib Pajak terhadap Kepatuhan Wajib Pajak.

Hasil penelitian ini mendukung hipotesis yang sudah di tentukan bahwa variabel Kualitas Pelayanan, Sanksi Pajak dan Kesadaran Wajib Pajak berpengaruh positif secara bersama-sama terhadap Kepatuhan Wajib Pajak pada Kecamatan Tanjungkerta Kabupaten Sumedang. Hal ini ditunjukkan oleh $F_{\text {hitung }}$ sebesar 33,688 lebih besar dari pada $\mathrm{F}_{\text {tabel }}$ sebesar 2,699 maka $\mathrm{H}_{4}$ diterima $\mathrm{H}_{0}$ ditolak dan juga jika dilihat dari nilai signifikansi sebesar 0,000 lebih kecil dari 0,05. Mengindikasikan bahwa kualitas pelayanan, sanksi pajak, dan kesadaran wajib pajak berpengaruh positif signifikan terhadap kepatuhan wajib pajak.

\section{KESIMPULAN DAN SARAN}

\section{Kesimpulan}

Berdasarkan hasil penelitian dan pembahasan yang telah diuraikan mengenai pengaruh kualitas pelayanan, sanksi pajak, dan kesadaran wajib pajak terhadap kepatuhan wajib pajak, penulis dapat menarik kesimpulan sebagai berikut :

1. Kualitas pelayanan berpengaruh positif dan signifikan terhadap kepatuhan wajib pajak. Hal ini berarti apabila kualitas pelayanan semakin baik maka mengakibatkan kepatuhan wajib pajak akan semakin tinggi. Begitupun sebaliknya, apabila kualitas pelayanan rendah, maka kepatuhan wajib pajak juga akan rendah. Kualitas pelayanan memberikan pengaruh sebesar $10,9 \%$ terhadap kepatuhan wajib pajak dalam membayar Pajak Bumi dan Bangunan pada Kecamatan 
Tanjungkerta.

2. Sanksi pajak berpengaruh positif dan signifikan terhadap kepatuhan wajib pajak. Hal ini berarti apabila sanksi pajak semakin tinggi (sesuai) sanksi pajak maka kepatuhan wajib pajak akan semakin tinggi. Begitu sebaliknya, apabila sanksi pajak semakin rendah maka kepatuhan wajib pajak juga akan rendah. Sanksi pajak memberikan pengaruh sebesar $18,3 \%$ terhadap kepatuhan wajib pajak dalam membayar Pajak Bumi dan Bangunan pada Kecamatan Tanjungkerta. Hal ini ditunjukkan oleh nilai koefisien regresi $\mathrm{X}_{2}$ sebesar 0,340 menyatakan bahwa setiap kenaikan sanksi pajak sebesar 1 poin maka akan meningkatkan kepatuhan wajib pajak sebesar 0,340 poin. Nilai $t_{\text {hitung }}$ yang lebih besar dari $t_{\text {tabel }}$ yaitu 3,155 > 1,985, maka $\mathrm{H}_{2}$ diterima $\mathrm{H}_{0}$ ditolak dan nilai signifikansi uji statistik (p-value) $(0,002)$ lebih kecil dari tingkat kesalahan yang dapat diterima sebesar 5\%, mengindikasikan bahwa sanksi pajak berpengaruh positif signifikan terhadap kepatuhan wajib pajak.

3. Kesadaran wajib pajak berpengaruh positif dan signifikan terhadap kepatuhan wajib pajak. Hal ini berarti apabila semakin tinggi kesadaran wajib pajak maka kepatuhan wajib pajak akan semakin tinggi. Begitu sebaliknya, apabila kesadaran wajib pajak semakin rendah maka kepatuhan wajib pajak juga akan rendah. Kesadaran wajib pajak memberikan pengaruh sebesar $22,1 \%$ terhadap kepatuhan wajib pajak dalam membayar Pajak Bumi dan Bangunan pada Kecamatan Tanjungkerta.

4. Kualitas pelayanan, sanksi pajak, serta kesadaran wajib pajak bersama-sama memberikan pengaruh sebesar 51,3\% terhadap kepatuhan wajib pajak dalam membayar Pajak Bumi dan Bangunan pada Kecamatan Tanjungkerta. Persamaan regresi hasil analisis berganda adalah $\mathrm{Y}=0,195+0,277 \mathrm{X}_{1}$ $+0,340 \mathrm{X}_{2}+0,390 \mathrm{X}_{3}$. Hal ini menunjukkan semakin baik kualitas pelayanan, sanksi pajak, dan kesadaran wajib pajak maka kepatuhan wajib pajak pada Kecamatan Tanjungkerta Kabupaten Sumedang juga semakin baik. Hal ini ditunjukkan oleh $\mathrm{F}_{\text {hitung }}$ sebesar 33,688 lebih besar dari pada $F_{\text {tabel }}$ sebesar

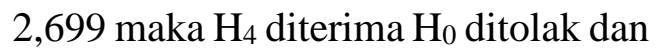
juga jika dilihat dari nilai signifikansi sebesar 0,000 lebih kecil dari 0,05. Berarti menunjukkan pengaruh positif dan signifikan antara variabel bebas dengan variabel terikat. 
pajak untuk patuh dalam membayar Pajak Bumi dan Bangunan.

\section{Saran}

Setelah peneliti melaksanakan penelitian dan pembahasan tentang pengaruh kualitas pelayanan, sanksi pajak dan kesadaran wajib pajak terhadap kepatuhan wajib pajak dalam membayar Pajak Bumi dan Bangunan pada Kecamatan Tanjungkerta Kabupaten Sumedang. Untuk hal tersebut peneliti memberikan usulan saran yang diharapkan dapat bermanfaat bagi penelitian selanjutnya, adapun saran tersebut yaitu :

1. Dalam kualitas pelayanan yang diberikan kepada wajib pajak baik berupa peningkatan Sumber Daya Manusia (SDM) maupun fasilitas lainnya sebaiknya dapat dilaksanakan dengan sebaik mungkin. Sehingga dapat mendorong wajib pajak untuk patuh melaksanakan kewajiban perpajakannya.

2. Sanksi perpajakan harus dapat ditingkatkan untuk disosialisasikan dengan baik kepada wajib pajak agar wajib pajak dapat memahami tentang hal-hal yang berkaitan dengan pelaksanan sanksi. Sehingga dengan memahami tentang hal-hal yang berkaitan dengan pelaksanaan sanksi tersebut, dapat mendorong wajib
3. Kesadaran wajib pajak pun harus dapat ditingkatkan dengan sikap emosional wajib pajak yang sadar akan hak dan kewajibannya sebagai warga negara mendorong untuk patuh membayar kewajiban perpajakannya. Selain itu aparat hendaknya lebih meningkatkan lagi berbagai penyuluhan terutama hal-hal yang berkaitan dengan Pajak Bumi dan Bangunan karena hal tersebut dapat membantu meningkatkan kepatuhan dalam membayar Pajak Bumi dan Bangunan. Wajib pajak hendaknya dapat lebih meningkatkan kepatuhannya dalam memenuhi kewajiban perpajakannya, dengan meningkatkan kesadaran terhadap hak dan kewajiban perpajakan, sehingga wajib pajak dapat berlaku jujur dalam melaporkan pajak terutangnya.

\section{DAFTAR PUSTAKA}

Alifa Nur Rohmawati dan Ni Ketut Rasmini (2012). Pengaruh Kesadaran, Penyuluhan, Pelayanan, dan Sanksi Perpajakan pada Kepatuhan Wajib Pajak Orang Pribadi. E-Jurnal Akuntans Universitas Udayana (Vol 1, No. 2). Hlm. 1-17. Jurusan Akuntansi Fakultas Ekonomi Universitas Udayana, Bali. 
JAFTA - Vol 3 Nomor 2, September (2021)

Bayu Caroko. 2015. Pengaruh Pengetahuan Perpajakan, Kualitas Pelayanan Pajak dan sanksi Pajak terhadap Motivasi Wajib Pajak Orang Pribadi dalam Membayar Pajak. Jurnal Perpajakan (JEJAK) (Vol. 1 No. 1) hlm. 1-10. Program Studi Perpajakan Fakultas Ilmu Administrasi Universitas Brawijaya, Malang.

Emielia Mareta, Siti Ragil Handayani, dan Achmad Husaini. (2014). "Pengaruh Pelaksanaan Sensus Pajak Nasional, Kualitas Pelayanan dan Pengetahuan Pajak terhadap Kepatuhan Wajib Pajak (Studi pada Wajib Pajak Orang Pribadi diu KPP Pratama Batu)". Jurnal. Hlm. 1-9. Program Studi Perpajakan Fakultas Ilmu Administrasi Universitas Brawijaya, Malang.

Fahmi, Hanifiyatun. 2016. Pengaruh Pengetahuan Perpajakan, Kualitas Pelayanan Pemerintah Daerah dan Kesadaran Oleh Wajib Pajak terhadap Kepatuhan Wajib Pajak dalam Pembayaran PBB. Jurnal Universitas Muhammadiyah Yogyakarta

Ghozali, Imam. 2018, Aplikasi Analisis Multivariate dengan Program SPSS, BPFE UNDIP, Semarang.

Halim Abdul, dkk. 2020. Perpajakan Konsep, Aplikasi, Contoh, dan Studi Kasus. Jakarta : Salemba Empat
Kotler, Philip and Kevin Lane Keller, 2016. Marketing Managemen, 15th Edition, Pearson Education,Inc

Kusuma Kartika Candra. 2016. Pengaruh Kualitas Pelayanan Pajak, Pemahaman Peraturan Perpajakan serta Sanksi Perpajakan terhadap Kepatuhan Wajib Orang Pribadi dalam Membayar Pajak pada tahun 2014. Skripsi. Hlm 25-28. Program Studi Akuntansi jurusan Pendidikan Akuntansi Fakultas Ekonomi Universitas Negeri Yogyakarta.

Hardiyansyah. 2018. Kualitas Pelayanan Publik : Konsep, Dimensi dan Implementasinya, Yogyakarta : Gava Media

Mardiasmo. 2019. Perpajakan, Yogyakarta : ANDI

Rahayu, Siti Kurnia. 2017. Perpajakan : Konsep dan Aspek Formal, Bandung : Rekayasa Sains

Resmi, Siti. 2017. Perpajakan Teori dan Kasus., Jakarta : Salemba Empat Rochmat Soemitro, Dewi Kania Sugiharti. 2014 . Asas dan Dasar Perpajakan I. Bandung:Edisi Revisi 1, PT.Refika Aditama

Sapriadi, Doni. 2013. "Pengaruh Kualitas Pelayanan Pajak, Sanksi Pajak, dan Kesadaran Wajib Pajak terhadap Kepatuhan Wajib Pajak dalam Membayar PBB”. Jurnal Universitas Negeri Padang 
Sari, Diana. 2013. Konsep Dasar Perpajakan, Bandung : PT Refika Aditama

Sony Devano, dan Siti Kurnia Rahayu. 2006. Perpajakan : Konsep, Teori dan Isu, Jakarta : Kencana

Sri Valentina, Suryo Aji. 2012. Perpajakan Indonesia. Yogya : Amp Ykpn

Suandy, Erly. 2016. Perencanaan Pajak (Edisi Keenam), Jakarta : Salemba Empat

Sugiyono. 2019. Metode Penelitian Kuantitatif, Kualitatif, dan $R \& D$, Bandung : ALFABETA

Sugiyono. 2020. Metode Penelitian

Kuantitatif, Kualitatif, dan $R \& D$, Bandung : ALFABETA

Waluyo. 2011. Perpajakan Indonesia, Jakarta : Salemba Empat 
JAFTA - Vol 3 Nomor 2, September (2021) 